\title{
TRANSFORMASI TARI BUNGKUS DI KABUPATEN SIMEULUE
}

\author{
PUTRI KHAIRANI \\ Prodi Pendidikan Tari
}

\begin{abstract}
The research discuis about transformation of bungkus dance in Simeulue Regency. The bungkus dance is one of traditional dance in the Simeulue Regency that comes from Sibolga Costal region. The purpose of the research is to understan the history and transformation bungkus dance in Simeulue Regency.

In the research discussion, used consist of three theories, such as history theory by Gilbert J, SJ, transformation theory by Sumaryono and Acculturation theory by Koentjaraningrat.

The method that used in this research discussion is kualitative descriptive method. The time research of bungkus dance transformation has done two month since september until october 2015. The population of research is all of Simeulue society and the sample of this research is the leader of tradition, informan, artists and general society who know about bungkus dance.

Based on the research that has done know that the transformation bungus dance can be seen from the style, feel and sense.
\end{abstract}

Keywords: History, Transformation, Bungkus Dance. 


\section{PENDAHULUAN}

\begin{tabular}{llrr}
\multicolumn{2}{c}{ Kabupaten } & Simeulue \\
merupakan & salah & satu & daerah \\
terpencil di & Aceh & yang & memiliki
\end{tabular}
berbagai macam budaya dan kesenian tradisi, baik itu kesenian musik maupun tari, seperti kesenian musik nandong dan tari silongor. Selain kesenian tradisi tersebut, kesenian yang terdapat di Kabupaten Simeulue juga ada yang berasal dari daerah luar Kabupaten Simeulue. Kesenian yang berasal dari daerah luar Kabupaten Simeulue mengalami adaptasi yang disesuaikan dengan adat istiadat di daerah setempat. Salah satunya adalah tari bungkus.

Tari bungkus adalah sebuah tari sapu tangan yang menceritakan tentang kisah awal perjumpaan sepasang muda-mudi daerah Pesisir Sumatera. Dari hasil penelitian yang dilakukan penulis pada tanggal 10 September 2015 di Kabupaten Simeulue kepada Bapak Juman (narasumber penulis yang merupakan keturunan dari salah satu murid Alm. Halilullah dan salah seorang seniman senior daerah di Kabupaten Simeulue) dapat diketahui bahwa tari bungkus berasal dari daerah Pesisir
Sibolga yang dibawakan oleh Alm. Halilullah pada akhir abad ke 18 atau sebelum tahun 1907.

Alm. Hailullah merupakan salah seorang pemuka agama dan budayawan yang berasal dari daerah Pesisir Minangkabau yang berimigrasi ke daerah Pesisir Sibolga untuk mendalami ajaran Agama Islam kemudian beliau melanjutkan perjalanannya ke Kabupaten Simeulue dengan tujuan melakukan menyebarkan ajaran Agama Islam di Kabupaten Simeulue. Beliau menyebarkan ajaran Agama Islam melalui seni dan budaya yang berasal dari daerah Pesisir Sibolga seperti tari bungkus. Tari bungkus yang diajarkan disesuaikan dengan hukum dan adat istiadat yang berlaku di daerah Kabupaten Simeulue. Tari bungkus yang telah diadaptasi tersebut terus diajarkan hingga pada akhir hayatnya beliau meninggal dunia di Kabupaten Simeulu dengan bukti autentik terdapatnya makam Alm. Hailullah di jalan Teungku Diujung Kabupaten Simeulue.

Berbeda dengan informasi yang telah dijelaskan diatas, menurut buku yang diterbitkan oleh 
pemerintah Kota Sibolga dengan judul Bunga Rampai Pesisir Kota Sibolga yang disusun oleh Sjawal Pasaribu (2014:88), tari sapu tangan berasal dari Pantai Barat Pesisir Tapanuli Tengah Sibolga. Tari sapu tangan ini menggambarkan bagaimana kisah dan cara perkenalan sepasang muda mudi pada zaman dahulu didaerah pesisir. Kejadiannya bermula dari perkenalan sepasang muda mudi pada saat para nelayan pulang dari menangkap ikan di pantai Barat Pesisr Tapanuli Tengah Sibolga. Dari tata cara perkenalan yang mereka lakukan didasari adat istiadat, terlukislah sebuah tata cara yang diperagakan dalam tarian yang bernama tari sapu tangan.

Dari kedua informasi mengenai asal usul tari bungkus tersebut ditemukan persepsi budaya yang berbeda. Hal tersebut menyebabkan munculnya varian tari sapu tangan yang berbeda. Perbedaan tersebut dapat jelas dilihat dari nama tari, bentuk penyajian, ragam gerak, iringan musik dan busana yang terdapat pada tari tersebut. Nama tari sapu tangan di kabupaten simeulue adalah tari bungkus.Nama dari Tari bungkus tersebut diambil dari sebuah pembungkus bekal yang menggunakan kain sebagai pembungkusnya dan diikatkan sebanyak dua kali. Apabila dihubungkaitkan dengan tari bungkus, nama dari tari bungkus tersebut diartikan sebagai permulaan kisah karena pembungkus tersebut merupakan bagian paling luar. Nama dari tari bungkus juga sangat berkaitan dengan adat istiadat di Kabupaten Simeulue karena ikatan dari pembungkus tersebut diikat sebanyak dua kali dan apabila dikaitkan dengan tari bungkus, ikatan pembungkus itu diibaratkan seperti sebuah rantai yang kuat sama halnya dengan Kabupaten Simeulue yang memiliki sebuah peraturan dan hukum adat istiadat yang sangat kuat. Selain nama, bentuk penyajian tari bungkus juga berbeda dengan tari sapu tangan Pesisir Sibolga. Jika pada tari sapu tangan daerah Pesisir Sibolga sepasang muda-mudi diperbolehkan untuk menari, maka berbeda halnya pada tari sapu tangan atau tari bungkus di Kabupaten Simeulue. Pada tari bungkus Kabupaten Simeulue yang 
diperbolehkan untuk menarikannya adalah sepasang muda-muda dan sepasang pasangan yang telah menikah. Hal tersebut dikarenakan adanya peraturan adat setempat yang berpedoman kepada syariat Islam. Namun seiring perkembangan zaman, tari bungkus tersebut saat ini hanyalah ditarikan oleh muda-muda saja dikarenakan adanya keterikatan pekerjaan bagi pasangan yang telah menikah baik itu pekerjaan rumah maupun pekerjaan untuk mencari nafkah. Sehingga banyak dintara pasangan yang telah menikah tersebut menolak untuk menarikan tari bungkus pada acara pernikahan maupun acara besar di Kabupaten Simeulue. Bukan hanya perbedaan pada bentuk penyajiannya saja yang dapat dilihat, ada beberapa perbedaan lainnya yang dapat dilihat pada tari bungkus Kabupaten Simeulue. Berdasarkan latar belakang yang telah diuraikan sebelumnya, penulis sangat tertarik untuk mengetahui lebih dalam dan mengangkatnya dalam suatu karya tulis ilmiah yang berjudul "Transformasi Tari Bungkus di Kabupaten Simeulue".

\section{Landasan Teori}

Untuk membahas transformasi tari bungkus di Kabupaten Simeulue maka penulis menggunakan teori sejarah dari Gilbert J. Garraghan, S.J, teori transformasi dari Sumaryono, dan teori akulturasi dari Koentjaraningrat.

\section{Lokasi dan Waktu Penelitian}

Lokasi penelitian ini dilakukan di Kabupaten Simeulue, Aceh. Waktu yang digunakan dalam penelitian ini adalah selama dua bulan yaitu dimulai dari awal bulan September 2015 sampai bulan Oktober 2015.

\section{Populasi dan Sampel \\ Populasi}

Yang menjadi obyek populasi dalam penelitian ini adalah tari bungkus sedangkan yang akan menajdi subyek populasi dalam penelitian ini adalah seluruh masyarakat Simeulue.

\section{Sampel}

Sampel pada penelitian ini yaitu ketua adat, narasumber, seniman, 
dan masyarakat umum yang mengetahui Tari Bungkus di Kabupaten Simeulue.

\section{Teknik Pengumpulan Data}

Teknik pengumpulan data yang dilakukan adalah sebagai berikut:

1. Studi kepustakaan

2. Observasi

3. Wawancara

4. Dokumentasi

\section{Teknik Analisis Data}

Dalam penelitian ini data yang digunakan adalah analisis deskriptif kualitatif dimana penelitian ini sesuai dengan fakta sosial dan memberi gambaran, keterangan serta uraian.

\section{ISI}

\section{Gambaran Umum Kabupaten}

\section{Simeulue}

Kabupaten Simeulue adalah salah

satu kabupaten di Aceh, Indonesia.

Berada kurang lebih $150 \mathrm{~km}$ dari lepas pantai barat Aceh, Kabupaten Simeulue berdiri tegar di Samudera Indonesia. Kabupaten Simeulue merupakan pemekaran dari Kabupaten Aceh Barat sejak tahun 1999, dengan harapan pembangunan semakin ditingkatkan di kawasan ini.Ibukota Kabupaten Simeulue adalah Sinabang.

Kabupaten Simeulue merupakan salah satu daerah terpencil di Aceh yang memiliki berbagai macam kesenian tradisi, baik itu kesenian musik maupun tari, seperti kesenian musik nandong dan tari silongor. Selain kesenian tradisi tersebut, kesenian yang terdapat di Kabupaten Simeulue juga ada yang berasal dari daerah luar Kabupaten Simeulue. Kesenian yang berasal dari daerah luar Kabupaten Simeulue mengalami adaptasi yang disesuaikan dengan adat istiadat di daerah setempat. Salah satunya adalah tari bungkus.

\section{Sejarah Tari Bungkus di}

\section{Kabupaten Simeulue}

Tari Bungkus adalah sebuah tari tradisional yang berasal dari daerah Pesisir Pulau Sumatera tepatnya dari daerah Pesisir Sibolga. Tari Bungkus merupakan tari sapu tangan yang menggambarkan tentang awal pertemuan sepasang muda mudi. Tari 
bungkus ini dibawa dan diajarkan ke daerah Pesisir Kabupaten Simeulue oleh Alm. Halilullah pada akhir abad ke 18 atau sebelum tahun 1907 yaitu pada zaman kolonial Belanda atau sebelum terjadinya Smong untuk yang pertama kali di Kabupaten Simeulue.

Tari bungkus yang diajarkan oleh Alm. Hailullah mengalami beberapa perubahan, perubahan tersebut terjadi dikarenakan adanya penyesuaian atau adaptasi dengan hukum dan adat istiadat yang berlaku di daerah Kabupaten Simeulue. Tari bungkus yang telah diadaptasi tersebut awalnya diajarkan Alm. Halilullah hanya kepada pemuda-pemuda Kabupaten Simeulue setiap hari dan ditampilkan ketika diadakannya acara-acara besar di Kabupaten Simeulue. Hal tersebut dikarenakan dalam hukum adat yang berlaku di Kabupaten Simeulue menyatakan bahwa seorang wanita tidak diperbolehkan untuk menari. Menurut hukum adat Kabupaten Simeulue, wanita adalah perhiasan dunia yang harus tetap dijaga dan dilindungi. Wanita Simeulue juga tidak diperbolehkan untuk berada diluar rumah dalam waktu yang lama terlebih untuk berkomunikasi dengan lelaki yang bukan muhrimnya.

Tari bungkus yang telah diadaptasi tersebut secara terus-menerus diajarkan Alm. Halilullah hingga pada akhir hayatnya. Beliau meninggal dunia dan dimakamkan di Gampong Latak Ayah, Kecamatan Simeulue Cut, Kabupaten Simeulue dengan bukti otentik terdapatnya makam Alm. Hailullah di jalan Teungku Diujung, Gampong Latak Ayah, Kecamatan Simeulue Cut, Kabupaten Simeulue.

\section{Proses Transformasi}

Proses terjadinya transformasi pada tari bungkus di Kabupaten Simeulue terjadi karena adanya budaya luar yaitu budaya dari daerah Pesisir Sibolga yang masuk ke Kabupaten Simeulue. Budaya tersebut dibawa ke kabupaten Simeulue oleh Alm. Halilullah berupa bahasa dan kesenian-kesenian daerah Pesisir Sibolga seperti tari-tarian. Budaya tersebut tidak mudah untuk diterima olah masyarakat Kabupaten Simeulue karena Kabupaten Simeulue memiliki budaya yang 
berbeda dengan budaya pesisir yang dibawakan oleh Alm. Halilullah. Budaya di Kabupaten Simeulue sangat erat kaitannya dengan adat istiadat yang berlaku di Kabupaten Simeulue sehingga apabila budaya luar yang dibawa harus dapat beradaptasi dengan adat istiadat yang berlaku di Kabupaten Simeulue.

\section{Transformasi Tari Bungkus}

Sebelum membahas

mengenai transformasi tari bungkus di Kabupaten Simeulue, terlebih dahulu diketahui bagaimana bentuk tari bungkus atau yang biasa dikenal oleh masyarakat Pesisir Sibolga sebagai tari sapu tangan. Tari sapu tangan adalah sebuah tari tradisional yang berasal dari daerah Pesisir Pulau Sumatera tepatnya dari daerah Pesisir Sibolga. Tari sapu tangan menceritakan tentang awal pertemuan sepasang muda mudi.

Seperti proses adaptasi yang dilakukan oleh Alm. Halilullah ketika mengajarkan keseniankesenian daerah Pesisir Sibolga kepada masyarakat Kabupaten Simeulue. Salah satunya yaitu tari bungkus. Tari Bungkus ini dibawa dan diajarkan ke daerah Pesisir Kabupaten Simeulue oleh Alm. Halilullah. Seperti yang telah dibahas sebelumnya tari bungkus ini mengalami proses adaptasi dengan kebudayaan dan adat istiadat di Kabupaten Simeulue sehingga menghasilkan suatu perubahan bentuk yang baru.

Dari proses adaptasi yang telah dilakukan Alm. Halilullah, tari sapu tangan daerah Pesisir Sibolga berubah nama dan wujudnya menjadi sebuah tarian yang baru yang disebut masyarakat Kabupaten Simeulue dengan tari bungkus. nama dari tari bungkus tersebut diambil dari sebuah pembungkus bekal yang menggunakan kain sebagai pembungkusnya dan diikatkan sebanyak dua kali. Apabila dihubungkaitkan dengan tari bungkus, nama dari tari bungkus tersebut diartikan sebagai permulaan kisah karena pembungkus tersebut merupakan bagian paling luar. Nama dari tari bungkus juga sangat berkaitan dengan adat istiadat di Kabupaten Simeulue karena ikatan dari pembungkus tersebut diikat sebanyak dua kali dan apabila 
dikaitkan dengan tari bungkus, ikatan pembungkus itu diibaratkan seperti sebuah rantai yang kuat sama halnya dengan Kabupaten Simeulue yang memiliki sebuah peraturan dan hukum adat istiadat yang sangat kuat. Adapun perubahan wujud tersebut dapat dilihat dari unsur-unsur kebaruan yang meliputi rupa, rasa, gaya dan makna

Transformasi Tari Bungkus di Kabupaten Simeulue

\section{A. Rupa}

Rupa memiliki arti segala hal-hal yang dapat dilihat wujud dan bentuknya secara nyata. Dalam tari bungkus, yang dapat dilihat wujud dan bentuknya secara nyata terdiri dari bentuk gerak, busana, dan alat musik.

\section{Transformasi Bentuk Tari}

\section{Bungkus Dilihat Dari Gerak}

Dilihat dari geraknya, tari sapu tangan Pesisir Sibolga dengan tari bungkus Kabupaten Simeulue samasama memiliki empat ragam gerak. Meskipun sama-sama memiliki jumlah ragam gerak yang sama, namun jumlah gerak di dalam ragam geraknya berbeda. Selain itu, bentuk geraknya juga sangat berbeda. Apabila pada tari sapu tangan Pesisir Sibolga gerakan kakinya dihenjut, berbeda dengan tari bungkus di Kabupaten Simeulue yang kakinya tidak dihenjut.

\section{Transformasi Bentuk Tari Bungkus Dilihat Dari Pola Lantai}

Selain bentuk geraknya yang berbeda, pola lantai dan bentuk penyajian pada tari bungkus Kabupaten Simeulu ini juga memiliki perbedaan. Pola lantai tari bungkus yaitu membentuk angka delapan pada ragam intinya. Angka delapan tersebut dilihat dari sebuah bungkusan kain yang diikatkan sebanyak dua kali dan diibaratkan sebuah rantai yang memiliki makna bahwa di Kabupaten Simeulue memiliki adat istiadat yang saling berkaitan dan sangat mempengaruhi sistem kemasyarakatan di Kabupaten Simeulue. Untuk itu ketika melakukan sebuah perkenalan seorang pemuda dan pemudi haruslah tetap berpegang teguh pada adat istiadat yang ada. 


\section{Transformasi Bentuk Tari}

\section{Bungkus Dilihat Dari Penari}

Penari pada tari bungkus Kabupeten Simeulue adalah sebanyak dua orang. Pada tari bungkus di Kabupaten Simeulue yang diperbolehkan untuk menarikannya adalah sepasang muda-muda dan sepasang pasangan yang telah menikah. Hal tersebut dikarenakan adanya peraturan adat setempat yang berpedoman kepada syariat Islam. Namun seiring perkembangan zaman, tari bungkus tersebut saat ini hanyalah ditarikan oleh muda-muda saja dikarenakan adanya keterikatan pekerjaan bagi pasangan yang telah menikah baik itu pekerjaan rumah maupun pekerjaan untuk mencari nafkah. Sehingga banyak dintara pasangan yang telah menikah tersebut menolak untuk menarikan tari bungkus pada acara pernikahan maupun acara besar di Kabupaten Simeulue. Bentuk penyajian yang berubah juga mempengaruhi fungsi dari tari bungkus meskipun samasama berfungsi sebagai tari hiburan namun tari bungkus pada saat ini lebih dikenal dengan sebuah tari pergaulan bukanlah tari percintaan.

\section{Transformasi Bentuk Tari} Bungkus Dilihat

\section{DariInstrument}

Instrument Tari Sapu Tangan

Pesisir Sibolga

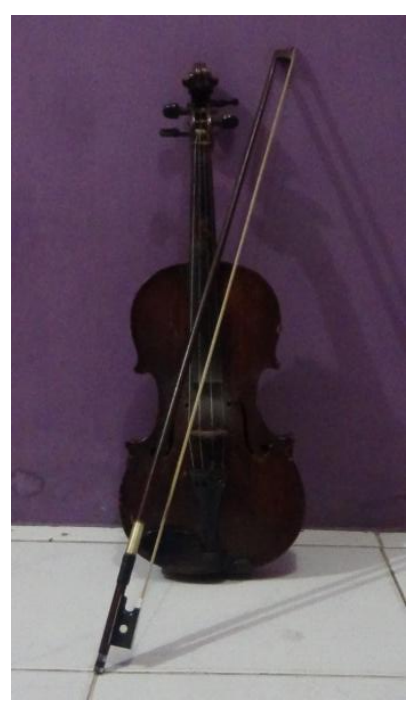

Gambar. Biola

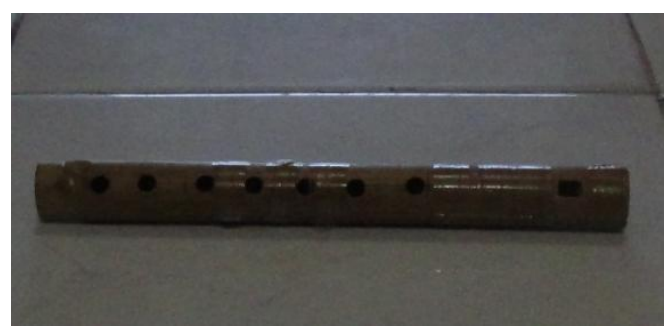

Gambar. Singkadu

\section{Instrument Tari Bungkus}

Kabupaaten Simeulue 
Gambar. Alat Musik Pada Tari Bungkus

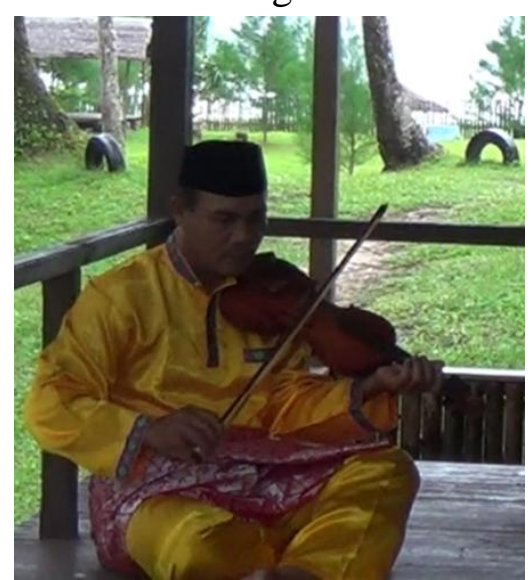

Gambar. Pemain dan Alat Musik Biola pada Tari Bungkus Kabupaten Simeulue

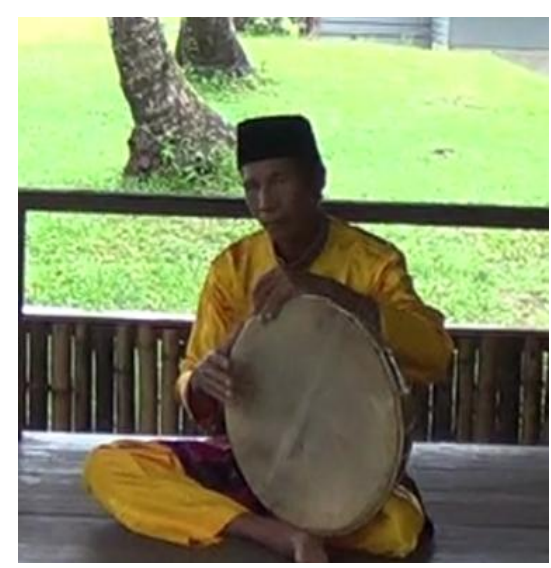

Gambar. Alat musik gendang yang digunakan pada tari bungkus di Kabupaten Simeulue.

\section{Transformasi Bentuk Tari}

\section{Bungkus Dilihat Dari Busana}

Busana yang digunakan pada tari bungkus mengalami perubahan pada rupa dan fungsinya. Apabila pada zaman dahulu busana yang digunakan penari pada tari bungkus adalah hanya baju yang sopan dan menutup aurat untuk penari lakilaki, baju kurung serta rok panjang dan menutupi aurat untuk penari perempuan maka sejak terbentuknya pemerintahan Kabupaten Simeulue busana yang digunakan penari pada tari bungkus tersebut adalah menggunakan teluk belanga, celana panjang, dan songket atau kain sarung untuk penari laki-laki sedangkan untuk penari perempuan menggunakan baju kurung dan rok panjang. Untuk warna pakaian yang digunakan penari dan pemusik haruslah berwarna kuning. Karena menurut adat istiadat Kabupaten Simeulue warna kuning adalah warna yang biasa digunakan oleh pihak kerajaan Kabupaten Simeulue serta sebagai lambang kebijaksanaan serta keagungan raja.

Busana yang digunakan oleh penari dan pemusik pada tari sapu tangan Pesisir Sibolga sama dengan busana yang digunakan oleh penari dan pemusik pada tari bungkus Kabupaten Simeulue, hanya saja pada tari sapu tangan Pesisir Sibolga busana yang digunakan oleh penari dan pemusik tidak diharuskan menggunakan busana warna kuning. 


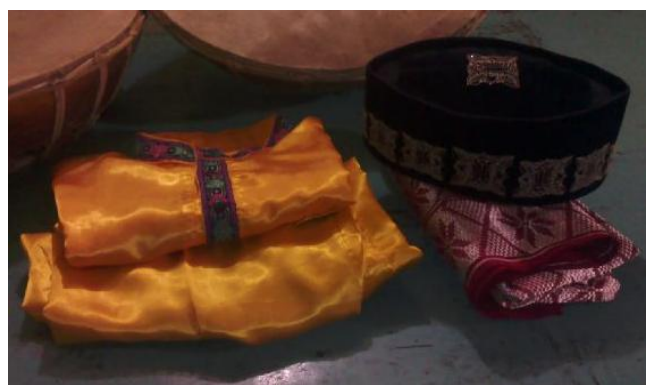

Gambar. Busana yang digunakan penari dan pemusik pada tari bungkus Kabupaten Simeulue

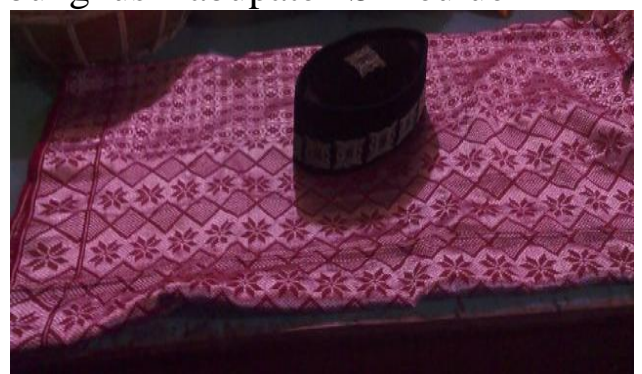

Gambar. Peci dan kain songket yang digunakan penari dan pemusik pada tari bungkus Kabupaten Simeulue

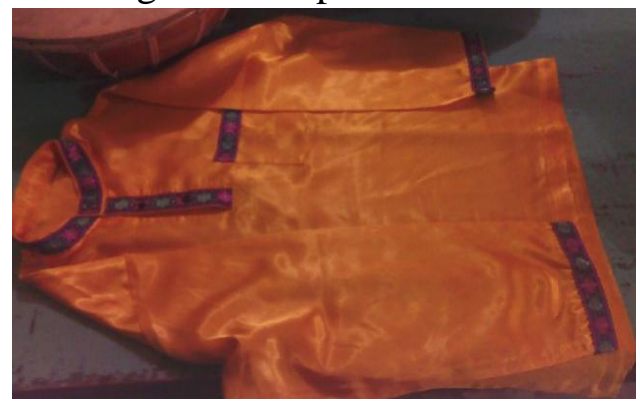

Gambar. Teluk belangatari bungkus Kabupaten Simeulue

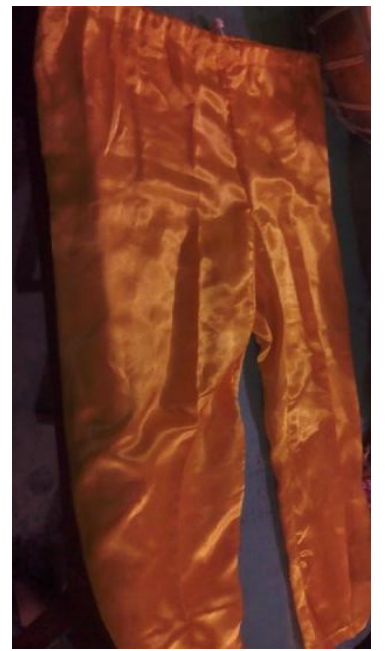

Gambar. Celana yang digunakan penari dan pemusik pada tari bungkus Kabupaten Simeulue

\section{B. Gaya}

Setiap daerah memiliki gaya atau ciri khas masing-masing dalam menari. Ciri khas tersebut ada dikarenakan adanya suatu aturan maupun kebiasaan masyarakat dalam menari. Di dalam tari bungkus terdapat gaya atau etika dalam menari, etika tersebut disesuaikan dengan peraturan adat yang berlaku di Kabupaten Simeulue. Tari bungkus Kabupaten Simeulu memiliki gaya yang lebih tegas dibandingkan dengan gaya pada tari sapu tangan Pesisir Sibolga.

\begin{tabular}{|c|c|}
\hline \multicolumn{2}{|c|}{ Gaya } \\
\hline Sibolga & Simeulue \\
\hline $\begin{array}{lr}\text { Tari } & \text { Sapu } \\
\text { Tangan } & \text { Pesisir } \\
\text { Sibolga } & \text { memilki } \\
\text { gerakan } & \text { yang } \\
\text { tidak } & \text { begitu } \\
\text { tegas } & \end{array}$ & $\begin{array}{l}\text { Memiliki gerakan } \\
\text { yang lebih tegas } \\
\text { dari Tari Sapu } \\
\text { Tangan Pesisir } \\
\text { Sibolga }\end{array}$ \\
\hline $\begin{array}{l}\text { Gerakan kaki } \\
\text { dihenjut }\end{array}$ & $\begin{array}{l}\text { Gerakan kaki } \\
\text { tidak dihenjut }\end{array}$ \\
\hline
\end{tabular}




\section{Rasa}

Adanya adat istiadat yang berlaku di Kabupaten Simeulue mempengaruhi rasa dalam menarikan tari bungkus. Rasa tersebut hadir karena pantun yang terdapat pada musik yang meniringi tari bungkus tersebut berisikan tentang nasehat yang bersangkut paut dengan adat istiadat Kabupaten Simeulue. Pantun tersebut mengingatkan siapapun yang mendengar pantun tersebut akan adat istiadat yang berlaku di Kabupaten Simeulue.

\begin{tabular}{|l|lr|}
\hline \multicolumn{3}{|c|}{ Rasa } \\
\hline \multicolumn{2}{|c|}{ Sibolga } & \multicolumn{2}{c|}{ Simeulue } \\
\hline \multicolumn{2}{|c|}{ Rasa lebih } & Rasa lebih \\
mendalam & mendalam \\
karena didalam & karena didalam \\
syair rerisi & syair r berisi \\
tentang nasehat- & tentang & nasehat- \\
nasehat & nasehat \\
\hline
\end{tabular}

Tabel. Transformasi Rasa Pada Tari Bungkus

\section{Makna}

Makna yang terkandung didalam tari bungkus tersebut berisikan tentang nasehat mengenai batasan-batasan dalam sebuah pertemuan antara muda-mudi dan mengenai proses yang harus dilalui oleh sepasang muda-mudi ketika sedang melakukan pendekatan. Makna tersebut diambil dari hukum adat yang berlaku di Kabupaten Simeulue dan kemudian dituangkan kedalam syair sebagai lantunan untuk mengiringi tari bungkus tersebut.

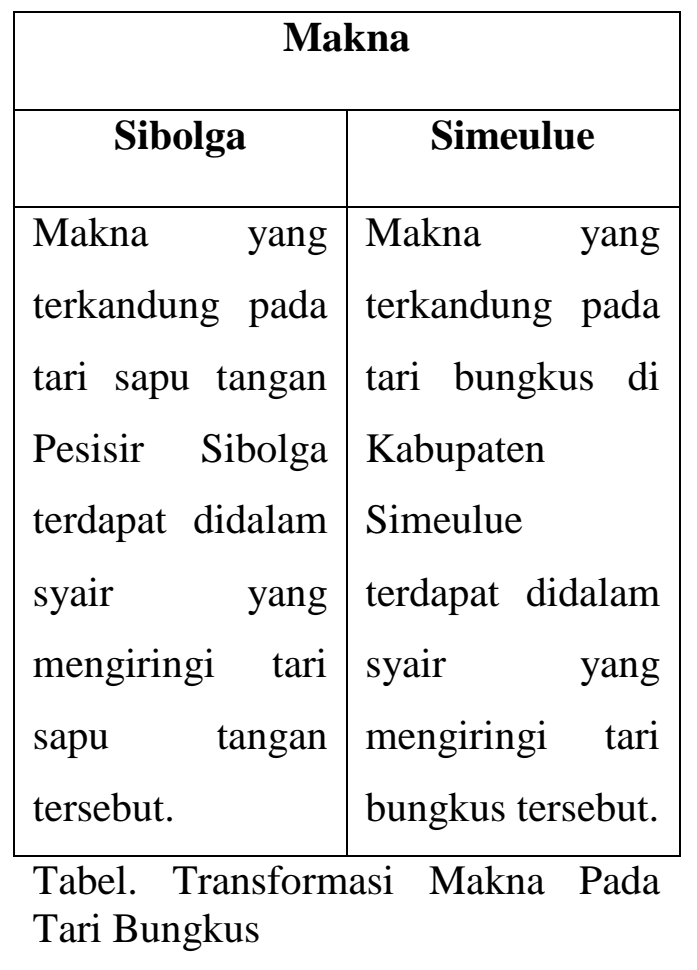

\section{PENUTUP}

\section{Kesimpulan}

Berdasarkan penelitian yang telah dilakukan dan diuaraikan didalam penulisan ini mulai dari latar belakang hingga pembahasan terhadap transformasi tari bungkus di Kabubaten Simeulue, maka secara 
keseluruhan dapat disimpulkan sebagai berikut :

1. Tari Bungkus merupakan sebuah tari tradisi yang berasal dari daerah Pesisir Sibolga yang kemudian oleh Hailullah pada tahun 1907 dibawa dan diajarkan ke daerah Pesisir Kabupaten Simeulue. Hailullah adalah salah seorang pemuka agama dan budayawan yang berasal dari daerah Pesisir Minangkabau yang berimigrasi ke daerah Pesisir Sibolga untuk mendalami ajaran agama Islam dan kemudian berlayar ke Kabupaten Simeulue dengan tujuan untuk menyiarkan ajaran agama Islam di Kabupaten Simeulue.

2. Dalam proses pengajarannya, tari bungkus mengalami perubahan. Perubahan tersebut terjadi karena adanya penyesuaian terhadap adat istiadat di Kabupaten Simeulue yang sangat dipegang teguh oleh masyarakat setempat.

3. Perubahan atau transformasi yang terjadi menghasilkan wujud yang baru dari tari sapu tangan. Wujud dari tari yang baru tersebut dinamakan tari bungkus. Wujud dari tari bungkus dapat dilihat dari rupa (bentuk gerak, pola lantai, penari, syair dan instrument, busana), gaya, rasa, dan makna.

\section{Saran}

Dari hasil kesimpulan penelitian diatas, maka dapat dihasilkan beberapa saran oleh penulis yang sangat diharapkan untuk diaplikasikan dalam kehidupan sehari-hari. Adapun beberapa saran tersebut antara lain sebagai berikut :

1. Penulis berharap dengan adanya penelitian ini masyarakatKabupaten Simeulue untuk menjaga, mengembangkan serta melestarikan kesenian asli Kabupaten Simeulu khususnya tari-tarian yang berada di Kabupaten Simeulue.

2. Diharapkan kepada masyarakat Kabupaten Simeulue khususnya kepada pemerintah daerah Kabupaten Simeulue dan pemerintah provinsi Nanggroe Aceh Darussalam senantiasa memperkenalkan berbagai kesenian asli dan tari-tarian khas Simeulue kepada masyarakat luas baik lokal maupun 
interlokal. Dengan begitu

keberadaan kesenian daerah dan

tari-tarian khas Kabupaten

Simeulue tersebut dapat dikenal

dan dipelajari oleh khalayak banyak.

3. Denganmenjaga,mengembangka n serta melestarikan dan meningkatkan kepedulian terhadap kesenian daerah, berarti telah menyelamatkan anak cucu kita dari pengaruh budaya luar yang akan merusak budaya sendiri.

\section{DAFTAR PUSTAKA}

Agus Sachari dan Yan Yan Sunarya. (1998) "Reformasi Budaya Kita sebuah wacana Dinamika, Desain dan Dunia Kesenirupaan di Indonesia”.

Koentjaraningrat. (2003). Pengantar Antropologi I. Jakarta: PT Rineka Cipta

(2009). Pengantar Ilmu Antropologi. PT Rineka Cipta

Moleong. (2014). Metodologi Penelitian Kualitatif. Edisi revisi. PT. Remaja Rosdakarya Bandung.

Nugrahaningsih, Yusnizar Heniwaty. (2012). Tari Identitas dan Resistensi. Medan :Unimed Press

Nurwani. (2014). Bahan Ajar Pengetahuan Seni Tari. Medan : Unimed Press

Nurwani (2015). Seni Dalam Perspektif Ilmu Sosial : Unimed Press

Pasaribu Sjawal. (2014). Bunga Rampai Pesisir Kota Sibolga. Pemerintah Kota Sibolga.

Pelly Usman. (1994). Urbanisasi dan Adaptasi:Peranan Misi Budaya Minangkabau dan Mandailing. Jakarta : Pustaka LP3ES Indonesia.

Ruwaida. (2014). Kesenian Sikambang: $\quad$ Prespektif 
Multikultural sebagai

Identitas Budaya Pesisir

Sibolga. Skripsi untuk memeuhi syarat Sarjana S-1 pada Program Studi Pendidikan Tari, Jurusan Sendratasik, Universitas Negeri Medan.

Sibarani Robert. (2014). Kearifan Lokal "Hakikat, Peran dan Metode Tradisi Lisan". Asosiasi Tradisi Lisan (ATL).

Sugiyono. (2010) Metode Penelitian Kuantitatif Kualitatif dan R\&D. Bandung : Alfabeta.

Sumaryono. (2003). Restorasi Seni

Tari dan Transformasi

Budaya. Yogyakarta : Ikaphi.

Yusmidar. (1999) Mengenal Tari

Tradisional Aceh”. Banda Aceh :

Dinas Kebudayaan 1999. 